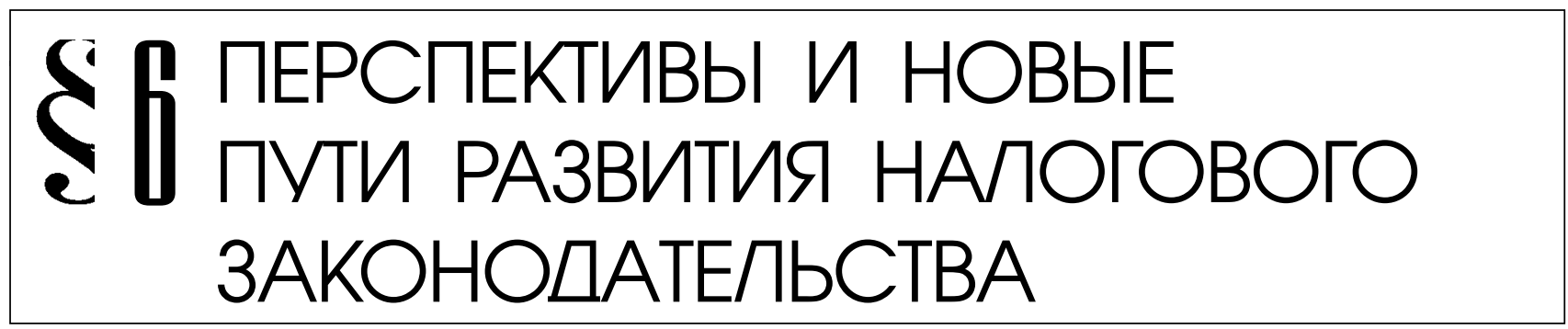

О.Ю. Горяченко

\title{
ВОПРОСЫ СИСТЕМЫ ИСТОЧНИКОВ РОССИЙСКОГО НАЛОГОВОГО ПРАВА
}

Аннотация: Статья посвящена рассмотрению вопросов системы источников российского налогового права. В данной статье раскрываются понятия «источники (формы) российского налогового права», "нормативные правовые акты по налогам и сборам», "подзаконный правовой акт в налоговой сфере» и другие. Автор статьи определил систему источников российского налогового права и в заключении сформировал вывод о том, что в современных правовых системах главными источниками российского налогового права являются нормативные акты, среди которых приоритетное место занимают законы как акты высшей юридической силы, которые в налоговой срере называются налоговым законодательством. Методом исследования являются источники российского налогового права.Под источниками (формы) российского налогового права понимается официально определенные внешние формы, в которых содержатся нормы, регулирующие отношения, возникающие в прочессе налогообложения. В указанных актах содержится нормативное толкование норм налогового права, которые предопределяют последующую складывающуюся правоприменительную практику, а также становление и укрепление налоговой законности в Российской Федерации. Автор статьи делает вывод, что в современных правовых системах главными источниками российского налогового права являются нормативные акты, среди которых приоритетное место занимают законы как акты высшей юридической силы, которые в налоговой сфере называются налоговым законодательством.

Ключевые слова: источники налогового права, правовые нормы, система, нормативные правовые акты, международные договоры, нормотворческие акты судов., налог и сбор, орган государственной власти, орган местного самоуправления, гражданин.

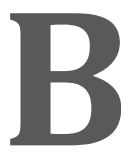

рамках каждой правовой системы «источники права, выстроенные по принципу их иерархической соподчиненности, которые образуют систему источников права». ${ }^{1}$

Правовые нормы, содержащиеся в источниках более низкой юридической силы, не могут противоречить предписаниям

\footnotetext{
1 Нерсесянц В.С. Общая теория государства и права. Учебник для вузов. Издательство: Норма, 2004. С. 266.
}

источников более высокой юридической силы. В различных правовых системах (семьях) вопрос о соподчиненности тех или иных видов источников права решается по-разному.

К источникам права, в том числе и налогового, принято относить различные нормативные правовые акты, содержащие соответствующие нормы права.

Так, под источниками (формы) российского налогового права понимается офи- 
циально определенные внешние формы, в которых содержатся нормы, регулирующие отношения, возникающие в процессе налогообложения. ${ }^{2}$

Система источников права во многом предопределяется историческим этапом развития общества и особенностями правовых систем.

Учитывая, специфику предмета регулирования налоговым правом, а также традиции правового регулирования властных отношений в России обусловили следующую систему источников российского налогового права:

- нормативные правовые акты;

- общепризнанные принципы междуна-

родного права и международные договоры;

- нормотворческие акты судов.

Однако в юридической литературе также отмечено, что развитие федеративных начал в построении российского государства обусловило и сложную разветвленную систему источников российского налогового права, в которой выделяются правовые акты федерального, регионального и муниципального уровней.

Так, нормативные правовые акты представляют собой наиболее значительную группу источников российского налогового права. Это объясняется тем, что для возникновения налоговых отношений необходима четко выраженная воля государства, которая объективизируется в нормативных правовых актах.

Нормативный правовой акт по налогам и сборам - это правовой акт, принятый уполномоченными органами государственной власти и органами местного самоуправления, который закрепляет нор-

2 Тютин Д.В. Налоговое право: курс лекций. Издательство - РАП; Эксмо, 2009. С. 23-28. мы, регулирующие налоговые отношения, рассчитанные на многократное применение и адресованные неограниченному кругу лиц.

В свою очередь, нормативные правовые акты подразделяются на законы и подзаконные акты.

Закон представляет собой нормативный правовой акт, принятый высшим государственным органом или непосредственно народом, обладающий высшей юридической силой. В данном определении содержится указание на два существенных признака закона:

- нормативный правовой акт принимается высшим органом государственной власти, имеющим возможность выражать волю государства;

- закон обладает высшей юридической силой.

Например, в системе источников российского налогового права среди законов выделяют Конституцию Российской Федерации, как главный закон Российской Федерации, который определяет правовую основу государства, закрепляющий основные права и свободы граждан, определяющий основы функционирования органов государственной власти и содержит основополагающие нормы, необходимые для дальнейшего регулирования налоговых отношений. ${ }^{4}$

Также, среди законов в источниках российского налогового права выделяют специальные и общие законы. К специальным относятся:

\footnotetext{
3 Марченко М.Н. Особенности нормативно-правового договора как источника права // Вестник Московского университета. Сер. 11. Право. 2007. № 1. С. 19-21.

4 Брызгалин А.В. Система налогового законодательства и проблемы его кодификации // Вестник гуманитарного университета. Серия «Право». Екатеринбург, 2008. № 1. - C. 76 .
} 
- Налоговый кодекс Российской Федерации (далее - НК РФ) ${ }^{5}$ и федеральные законы о налогах и сборах, принятые в соответствии с НК РФ;

- законы и иные нормативные акты законодательных (представительных) органов субъектов РФ;

- нормативные акты представительных органов местного самоуправления.

Следует отметить, что система нормативных правовых актов, объединяющих федеральные законы, законы субъектов Российской Федерации и нормативные правовые акты муниципальных образований, образует законодательство о налогах и сборах.

К общим законам относятся иные федеральные законы, содержащие нормы налогового права.

Подзаконный правовой акт в налоговой сфере представляет собой акт правотворчества, который исходит от компетентного государственного органа, изданный на основе и во исполнение закона и содержащий нормы налогового права.

Он подразделяется на два вида: акт органов общей компетенции и акт органов специальной компетенции.

К акту органов общей компетенции относятся:

- указы Президента РФ, которые не должны противоречить Конституции РФ и налоговому законодательству РФ и имеют приоритетное значение по отношению к другим подзаконным

\footnotetext{
5 Налоговый кодекс Российской Федерации. Часть первая от 31 июл. 1998 г. № 146-ФЗ: принят Гос. Думой 16 июл. 1998 г.: одобр. Советом Федерации 17 июл. 1998 г. // Рос. газ. - 1998, - 8 авг; Собр. законодательства Рос. Федерации. - 1998. - № 31, ст. 3824. Часть вторая от 5 авг. 2000 г. № 117-Ф3: принят Гос. Думой 19 июл. 2000 г.: одобр. Советом Федерации 26 июл. 2000 г.// Собр. законодательства Рос. Федерации. - 2000. - № 32, ст. 3340; Парлам. Газ. — 2000. — 10 авг., № 151-152.
}

актам. Указы могут приниматься по любому вопросу, входящему в компетенцию Президента РФ (ст. 90 Конституции РФ), в том числе по вопросам, составляющим предмет налогового права, кроме случаев, когда этот вопрос в соответствии с НК РФ может быть урегулирован только законом.

Отметим, что начиная с 1991 года Президентом РФ, было принято большое количество указов Президента РФ по вопросам налогообложения. С принятием части первой НК РФ принятые до ее введения указы Президента РФ по вопросам налогообложения, противоречащие НК РФ, в соответствии с Указом Президента РФ от 3 августа 1999 г. № 977 «0 приведении актов Президента РФ в соответствие с частью первой Налогового кодекса РФ» признаны утратившими силу. ${ }^{6}$

- постановления Правительства РФ. В соответствии с пунктом «б» части 1 статьи 114 Конституции РФ Правительство РФ обеспечивает проведение в Российской Федерации единой финансовой и налоговой политики. Постановления Правительства РФ принимаются на основании и во исполнение нормативных правовых актов, имеющих высшую по сравнению с ними юридическую силу.

Примерами таких нормативных правовых актов могут служить постановления Правительства РФ от 6 апреля 1999 г. № 382 «0 перечнях сезонных отраслей и видов деятельности, применяемых для целей налогообложения» ${ }^{7}$, от 26 февраля 2004 г.

\footnotetext{
6 Указ Президента РФ от 3 августа 1999 г. № 977 «О приведении актов Президента РФ в соответствие с частью первой Налогового кодекса РФ». Собр. законодательства Рос. Федерации. — 1999. — № 32, ст. 4045.

7 Постановление Правительства РФ от 6 апреля 1999 г. № 382 «О перечнях сезонных отраслей и
} 
№ 110 «0 совершенствовании процедур государственной регистрации и постановки на учет юридических лиц и индивидуальных предпринимателей». ${ }^{8}$

В предусмотренных законодательством о налогах и сборах случаях Правительство РФ вправе издавать подзаконные нормативные правовые акты по вопросам, связанным с налогообложением и сборами, которые не могут изменять или дополнять законодательство о налогах и сборах. Однако следует отметить, что Правительство РФ вправе издавать акты, в которых могут устанавливаться:

- ставки федеральных налогов, в случаях, указанных в НК РФ, в порядке и в пределах, определенных НК РФ (п.1 ст. 53 НК РФ);

- порядок ведения Единого государственного реестра налогоплательщиков (п. 8 ст. 84 НК РФ);

- порядок и размеры выплат, причитающихся свидетелям, переводчикам, специалистам, экспертам и понятым (п. 4 ст. 131 НК РФ) и др.

- подзаконные нормативные правовые акты по вопросам, связанным с налогообложением и сборами, принятые органами исполнительной власти субъектов РФ. Органы исполнительной власти субъектов РФ в предусмотренных законодательством о налогах и сборах случаях также издают нормативные правовые акты по вопросам, связанным с

видов деятельности, применяемых для целей налогообложения». Собр. законодательства Рос. Федерации. 1999. — № 15, ст. 1827; Рос. Газ. — 1999. — 21 апр. № 76.

8 Постановление Правительства РФ от 26 февраля 2004 г. № 110 «О совершенствовании процедур государственной регистрации и постановки на учет юридических лиц и индивидуальных предпринимателей» // Собр. законодательства Рос. Федерации. - 2004. № 10 , ст. 864 . налогообложением и сборами, которые не могут изменять или дополнять законодательство о налогах и сборах (п. 1 ст. 4 НК РФ).

- подзаконные нормативные правовые акты по вопросам, связанным с налогообложением и сборами, принятые исполнительными органами местного самоуправления. Исполнительные органы местного самоуправления в предусмотренных законодательством о налогах и сборах случаях также издают нормативные правовые акты по вопросам, связанным с налогообложением и сборами, которые не могут изменять или дополнять законодательство о налогах и сборах (п. 1 ст. 4 НК РФ). ${ }^{9}$

К подзаконному нормативному правовому акту органов специальной компетенции относятся ведомственные акты по вопросам, связанным с налогообложением и сборами органов специальной компетенции, издание которых прямо предусмотрено НК РФ. Такие нормативные правовые акты не могут изменять или дополнять законодательство о налогах и сборах. К органам специальной компетенции относятся:

- Министерство финансов Российской Федерации;

- едеральная налоговая служба;

- Федеральная таможенная служба;

- органы государственных внебюджетных фондов и другие органы государственной власти. ${ }^{10}$

Так, например, в соответствии с положениями НК РФ ведомственными нормативными правовыми актами Федеральная налоговая служба утверждает формы:

\footnotetext{
9 Крохина Ю.А. Налоговое право. Учебник для бакалавров. Издательство: Юрайт, 2013. С. 82-95.

10 Белых В.С., Винницкий Д.В. Налоговое право России. Издательство - Норма, 2009. С. 18-24.
} 
- $\quad$ требования об уплате налога (п. 5 ст. 69 НК РФ);

- налоговых уведомлений (ст. 52 НК РФ);

- $\quad$ заявления и свидетельства о постановке налогоплательщика на учет, порядок и условия присвоения, применения, а также изменения идентификационного номера налогоплательщика (ст. 84 НК РФ).

Также, к числу ведомственных актов следует отнести согласованные между Министерством финансов Российской Федерации и Федеральной налоговой службой. Так, например, приказ Минфина России, ФНС России от 20 февраля 2012 г. № ММВ-711/99@«Об утверждении формы и формата представления налоговой декларации по транспортному налогу в электронном виде и порядка ее заполнения». ${ }^{11}$

В соответствии с частью 4 статьи 15 Конституции Российской Федерации общепризнанные принципы и нормы международного права и международные договоры Российской Федерации являются составной частью ее правовой системы. Конституционное положение отражено и в статье 7 НК РФ, согласно которой в случае, если международным договором, содержащим положения, касающиеся налогообложения и сборов, установлены иные правила и нормы, чем предусмотренные законодательством о налогах и сборах, то применяются правила международных договоров.

Таким образом, нормы международных договоров могут содержать нормы налогового права, и эти нормы обязательны для

11 Приказ ФНС России от 20 февраля 2012 г. № ММВ7-11/99@ (ред. от 26 октября 2012) «Об утверждении формы и формата представления налоговой декларации по транспортному налогу в электронном виде и Порядка ее заполнения» (Зарегистрировано в Минюсте России 29 марта 2012 г. № 23657) // Рос. Газ. — 2012. 13 июл., № 159. их соблюдения на территории Российской Федерации. Поэтому акты международного права относятся к источникам российского права, а те акты, которые затрагивают вопросы налогообложения, относятся к источникам российского налогового права.

Также следует отметить, что в соответствии с общим конституционным принципом российского права о приоритете норм международного права и международных договоров Российской Федерации в международном договоре могут быть установлены:

- общие принципы взаимодействия договаривающихся сторон в сфере налогообложения;

- соглашения, направленные на избежание двойного налогообложения;

- общие налоговые соглашения, которые охватывают все вопросы налогообложения;

- ограниченные налоговые соглашения, охватывающие лишь отдельные вопросы в налоговой сфере;

- соглашения, в которых наряду с другими вопросами рассматриваются налоговые вопросы;

- налоговые соглашения, касающиеся индивидуальных лиц и хозяйствующих организаций. ${ }^{12}$

Учитывая то, что Российская Федерация как активный участник международных отношений является стороной в значительном количестве международных договоров, а также участником многосторонних соглашений по вопросам налогообложения и сборов то, к числу международно-правовых источников российского налогового права следует отнести:

\footnotetext{
12 Петров А.В., Толкушкин А.В. Налоги и налогообложение: учебник для бакалавров. Издательство Юрайт, 2013. С. 35-41.
} 
- общеполитические многосторонние акты, в которых содержатся общие принципы налогообложения;

- двухсторонние или многосторонние политические договоры, содержащие правовые нормы о налогообложении;

- собственно налоговые соглашения и конвенции;

- договоры, соглашения и конвенции, заключенные СССР с другими странами, не утратившие юридическую силу.

Также следует отметить, что правовая система Российской Федерации, следуя традициям континентального европейского права, не отводит нормотворческим актам судов (далее - Судебные акты) столь важной роли в регулировании общественных отношений. Поэтому по данному вопросу имеются разные точки зрения таких авторов, как Г.А. Гаджиева ${ }^{13}$, М.В. Кучина ${ }^{14}$ и других.

Но, вместе с тем, влияние судебной практики на регулирование налоговых отношений достаточно велико.

Характеризуя роль Судебных актов в регулировании налоговых правоотношений, в юридической литературе отмечают, что «роль судебной практики в настоящее время сводится как к выявлению смысла большинства налоговых законов, учитывая их несовершенство, так и к выработке новых подходов, развивающих нормы налогового законодательства». Тем самым, признается активное участие судебных органов в регулировании налоговых отно-

13 Гаджиев Г. А. Правовые позиции Конституционного Суда Российской Федерации как источник конституционного права // Конституционное правосудие в посткоммунистических странах: Сборник докладов. М., 1999. C. 116-135.

14 Кучин М. В. Нормотворческая деятельность судебных органов Российской Федерации и судебный прецедент // Право и политика. 2000. № 5. С.8-14. шений. Так, например, в пункте 7 постановления Пленума ВАС РФ от 20 декабря 2006 г. № 65 «0 подготовке дела к судебному разбирательству» разъяснено, что судье необходимо в каждом случае при подготовке дела к судебному разбирательству проанализировать судебную практику применения законодательства, регулирующего спорные правоотношения. Исходя из пункта 5.1 постановления Пленума ВАС РФ от 12 марта 2007г. № 17, в соответствии с пунктом 1 статьи 311 АПК РФ может быть пересмотрен по вновь открывшимся обстоятельствам судебный акт, оспариваемый заявителем в порядке надзора и основанный на положениях законодательства, практика применения которых после его принятия определена Высшим Арбитражным Судом в постановлении Пленума или в постановлении Президиума Высшего Арбитражного Суда, в том числе принятого по результатам рассмотрения другого дела в порядке надзора. При обжаловании в апелляционном или кассационном порядке надзора судебного акта, основанного на положениях законодательства, практика применения которых после его принятия определена Высшим арбитражным Судом, суд апелляционной или кассационной инстанции учитывает правовую позицию Высшего Арбитражного Суда при оценке наличия оснований для изменения или отмены обжалуемого судебного акта. Таким образом, определение практики на уровне Высшего Арбитражного Суда происходит в том числе в постановлениях Президиума данного Суда по конкретным делам, что сближает их с судебными прецендентами.

Как правило, рассматривая конкретное дело, судебные инстанции истолковывают норму права применительно к конкретному спору, и зачастую подобное толкование порождает новое понимание воли законо- 
дателя, направленной на регулирование общественных отношений. ${ }^{15}$

Действующее законодательство Российской Федерации закрепляет за Высшим Арбитражным Судом Российской Федерации (далее - ВАС РФ) право давать разъяснения по вопросам судебной практики. Аналогичное право закреплено и за Верховным Судом Российской Федерации (далее - ВС РФ). Примерами таких Судебных актов могут служить, постановление Четырнадцатого Арбитражного Апелляционного суда от 30 июня 2011 г. по делу № A66-2006/2011 ${ }^{16}$, постановление Федерального Арбитражного суда Западно-Сибирского округа от 29 ноября 2013 г. по делу № A27-4195/2013 ${ }^{17}$, определение Верховного Суда Российской Федерации от 24 апреля 2013 г. № 66-АПГ13-3 ${ }^{18}$.

Таким образом, две высшие судебные инстанции Российской Федерации вправе давать руководящие разъяснения по практике применения законодательства. Обобщая судебную практику и давая соответствующие разъяснения, ВАС РФ и ВС РФ, по сути, осуществляют толкование норм права, конкретизируя положения законодательства и восполняя пробелы правового регулирования.

Также следует отметить, что неоценимое значение для формирования налогового законодательства РФ и для всего нормативно-правового регулирования налоговых отношений имеют акты Консти-

15 Сорокин В.В. Судебная практика как источник права: за и против // Сибирский юридический вестник. 2007. № 3. - C. 21 .

16 Постановление Четырнадцатого Арбитражного Апелляционного суда от 30 июня 2011 г. по делу № A66-2006/2011

17 Постановление Федерального Арбитражного суда Западно-Сибирского округа от 29 ноября 2013 г. по делу № А27-4195/2013.

18 Определение Верховного Суда Российской Федерации от 24 апреля 2013 г. № 66-АПГ13-3. туционного Суда Российской Федерации (далее - КС РФ). Например, Определение Конституционного суда Российской Федерации от 27 января 2011 г. № 96-0-0 19 и др.

Проверяя соответствие федеральных законов, конституций субъектов Российской Федерации, уставов и законов субъектов Российской Федерации нормам Конституции Российской Федерации, КС РФ выявляет и формулирует конституционные принципы налогообложения, которые впоследствии воплощаются в актах законодательства о налогах и сборах ${ }^{20}$.

Среди конкретных документов ВС РФ, ВАС РФ и КС РФ, имеющих большое значение для нормативного регулирования налоговых отношений, следует отнести такие, как:

- постановления Пленума ВС РФ и ВАС РФ;

- информационные письма Президиума ВАС РФ, которые связанны с применениями положений Налогового кодекса Российской Федерации;

- Постановления и определения КС РФ.

Таким образом, в вышеуказанных актах содержится нормативное толкование норм налогового права, предопределяющих последующую складывающуюся правоприменительную практику, а также становление и укрепление налоговой законности в Российской Федерации, которая обеспечивает надежную защиту имущественных прав налогоплательщиков, законных интересов государства.

Учитывая вышеизложенное, возможно сделать вывод, что в современных правовых системах главными источниками

\footnotetext{
19 Определение Конституционного суда Российской Федерации от 27 января 2011 г. № 96-О-О.

20 Грачева Е.Ю., Болтинова О.В. Налоговое право. Издательство: Проспект, 2012. С. 49-51.
} 
российского налогового права являются нормативные акты, среди которых приоритетное место занимают законы как акты высшей юридической силы, которые в налоговой сфере называются налоговым законодательством.

\section{Библиография:}

1. Нерсесянц В.С. Общая теория государства и права. Учебник для вузов. Издательство: Норма, 2004. С. 266.

2. Тютин Д.В. Налоговое право: курс лекций. Издательство-РАП; Эксмо, 2009. С. 2328.

3. Марченко М.Н. Особенности нормативно-правового договора как источника права // Вестник Московского университета. Сер. 11. Право. 2007. № 1. С. 19-21.

4. Брызгалин А.В. Система налогового законодательства и проблемы его кодификации // Вестник гуманитарного университета. Серия «Право». Екатеринбург, 2008. № $1 .-$ С. 76 .

5. Налоговый кодекс Российской Федерации. Часть первая от 31 июл. 1998 г. № 146ФЗ: принят Гос. Думой 16 июл. 1998 г.: одобр. Советом Федерации 17 июл. 1998 г.// Рос. газ. - 1998, - 8 авг.; Собр. законодательства Рос. Федерации. - 1998. - № 31, ст. 3824. Часть вторая от 5 авг. 2000 г. № 117-Ф3: принят Гос. Думой 19 июл. 2000 г.: одобр. Советом Федерации 26 июл. 2000 г.// Собр. законодательства Рос. Федерации. 2000. — № 32, ст. 3340; Парлам. Газ. — 2000. - 10 авг., № 151-152.

6. Указ Президента РФ от 3 августа 1999 г. № 977 «0 приведении актов Президента РФ в соответствие с частью первой Налогового кодекса РФ». Собр.законодательства Рос. Федерации. - 1999. - № 32, ст. 4045.

7. Постановление Правительства РФ от 6 апреля 1999 г. № 382 «0 перечнях сезонных отраслей и видов деятельности, применяемых для целей налогообложения». Собр. законодательства Рос. Федерации. - 1999. - № 15, ст. 1827; Рос. Газ. - 1999. 21 апр. № 76.

8. Постановление Правительства РФ от 26 февраля 2004 г. № 110 «0 совершенствовании процедур государственной регистрации и постановки на учет юридических лиц и индивидуальных предпринимателей» // Собр. законодательства Рос. Федерации. 2004. - № 10, ст. 864.

9. Крохина Ю.А. Налоговое право. Учебник для бакалавров. Издательство: Юрайт, 2013. С. 82-95.

10. Белых В.С., Винницкий Д.В. Налоговое право России. Издательство - Норма, 2009. C. $18-24$.

11. Приказ ФНС России от 20 февраля 2012 г. № ММВ-7-11/99@ (ред. от 26 октября 2012) «Об утверждении формы и формата представления налоговой декларации по транспортному налогу в электронном виде и Порядка ее заполнения» (Зарегистрировано в Минюсте России 29 марта 2012 г. № 23657) // Рос. Газ. - 2012. - 13 июл., № 159.

12. Петров А.В., Толкушкин А.В. Налоги и налогообложение: учебник для бакалавров. Издательство - Юрайт, 2013. С. 35-41. 
13. Гаджиев Г. А. Правовые позиции Конституционного Суда Российской Федерации как источник конституционного права // Конституционное правосудие в посткоммунистических странах: Сборник докладов. М., 1999. С. 116-135.

14. Кучин М. В. Нормотворческая деятельность судебных органов Российской Федерации и судебный прецедент // Право и политика. 2000. № 5. С. 8-14.

15. Сорокин В.В. Судебная практика как источник права: за и против // Сибирский юридический вестник. 2007. № 3. - С. 21.

16. Постановление Четырнадцатого Арбитражного Апелляционного суда от 30 июня 2011 г. по делу № A66-2006/2011

17. Постановление Федерального Арбитражного суда Западно-Сибирского округа от 29 ноября 2013 г. по делу № A27-4195/2013

18. Определение Верховного Суда Российской Федерации от 24 апреля 2013 г. № 66АПГ13-3.

19. Определение Конституционного суда от 27 января 2011 г. № 96-0-0.

20. Грачева Е.Ю., Болтинова О.В. Налоговое право. Издательство: Проспект, 2012. С. 49-51.

\section{References:}

1. Nersesyants V.S. Obshchaya teoriya gosudarstva i prava. Uchebnik dlya vuzov. Izdatel'stvo: Norma, 2004. S. 266.

2. Tyutin D.V. Nalogovoe pravo: kurs lektsii. Izdatel'stvo-RAP; Eksmo, 2009. S. 23-28.

3. Marchenko M.N. Osobennosti normativno-pravovogo dogovora kak istochnika prava // Vestnik Moskovskogo universiteta. Ser. 11. Pravo. 2007. № 1. S. 19-21.

4. Bryzgalin A.V. Sistema nalogovogo zakonodatel'stva i problemy ego kodifikatsii // Vestnik gumanitarnogo universiteta. Seriya «Pravo». Ekaterinburg, 2008. № 1. - S. 76.

5. Nalogovyi kodeks Rossiiskoi Federatsii. Chast' pervaya ot 31 iyul. 1998 g. № 146-FZ: prinyat Gos. Dumoi 16 iyul. 1998 g.: odobr. Sovetom Federatsii 17 iyul. 1998 g.// Ros. gaz. — 1998, 8 avg.; Sobr. zakonodatel'stva Ros. Federatsii. — 1998. — № 31, st. 3824. Chast' vtoraya ot 5 avg. 2000 g. № 117-FZ: prinyat Gos. Dumoi 19 iyul. 2000 g.: odobr. Sovetom Federatsii 26 iyul. 2000 g.// Sobr. zakonodatel'stva Ros. Federatsii. — 2000. — № 32, st. 3340; Parlam. Gaz. - 2000. - 10 avg., № 151-152.

6. Ukaz Prezidenta RF ot 3 avgusta 1999 g. № 977 «O privedenii aktov Prezidenta RF v sootvetstvie s chast'yu pervoi Nalogovogo kodeksa RF». Sobr.zakonodatel'stva Ros. Federatsii. - 1999. - № 32, st. 4045.

7. Postanovlenie Pravitel’stva RF ot 6 aprelya 1999 g. № 382 «0 perechnyakh sezonnykh otraslei i vidov deyatel'nosti, primenyaemykh dlya tselei nalogooblozheniya». Sobr. zakonodatel'stva Ros. Federatsii. — 1999. — № 15, st. 1827; Ros. Gaz. — 1999. — 21 apr. № 76.

8. Postanovlenie Pravitel'stva RF ot 26 fevralya 2004 g. № 110 «O sovershenstvovanii protsedur gosudarstvennoi registratsii i postanovki na uchet yuridicheskikh lits i individual'nykh predprinimatelei» // Sobr. zakonodatel'stva Ros. Federatsii. — 2004. № 10 , st. 864 .

9. Krokhina Yu.A. Nalogovoe pravo. Uchebnik dlya bakalavrov. Izdatel'stvo: Yurait, 2013. S. 82-95.

10. Belykh V.S., Vinnitskii D.V. Nalogovoe pravo Rossii. Izdatel'stvo - Norma, 2009. S. 18-24. 
11. Prikaz FNS Rossii ot 20 fevralya 2012 g. № MMV-7-11/99@ (red. ot 26 oktyabrya 2012) «Ob utverzhdenii formy i formata predstavleniya nalogovoi deklaratsii po transportnomu nalogu v elektronnom vide i Poryadka ee zapolneniya» (Zaregistrirovano v Minyuste Rossii 29 marta 2012 g. № 23657) // Ros. Gaz. — 2012. — 13 iyul., № 159.

12. Petrov A.V., Tolkushkin A.V. Nalogi i nalogooblozhenie: uchebnik dlya bakalavrov. Izdatel'stvo - Yurait, 2013. S. 35-41.

13. Gadzhiev G. A. Pravovye pozitsii Konstitutsionnogo Suda Rossiiskoi Federatsii kak istochnik konstitutsionnogo prava // Konstitutsionnoe pravosudie v postkommunisticheskikh stranakh: Sbornik dokladov. M., 1999. S. 116-135.

14. Kuchin M. V. Normotvorcheskaya deyatel'nost' sudebnykh organov Rossiiskoi Federatsii i sudebnyi pretsedent // Pravo i politika. 2000. № 5. S. 8-14.

15. Sorokin V.V. Sudebnaya praktika kak istochnik prava: za i protiv // Sibirskii yuridicheskii vestnik. 2007. № 3. - S. 21.

16. Postanovlenie Chetyrnadtsatogo Arbitrazhnogo Apellyatsionnogo suda ot 30 iyunya $2011 \mathrm{~g}$. po delu № A66-2006/2011

17. Postanovlenie Federal'nogo Arbitrazhnogo suda Zapadno-Sibirskogo okruga ot 29 noyabrya 2013 g. po delu № A27-4195/2013

18. Opredelenie Verkhovnogo Suda Rossiiskoi Federatsii ot 24 aprelya 2013 g. № 66-APG13-3.

19. Opredelenie Konstitutsionnogo suda ot 27 yanvarya 2011 g. № 96-0-0.

20. Gracheva E.Yu., Boltinova O.V. Nalogovoe pravo. Izdatel'stvo: Prospekt, 2012. S. 49-51. 